\title{
Historií výchovy v přírodě v Čechách k lipnické Prázdninové škole
}

\author{
Otakar Holec \\ Prázdninová škola Lipnice \\ Redakci zasláno 15. 12. 2020 / upravená verze obdržena 2. 4. 2021 / \\ / k uveřejnění přijato 2. 4. 2021
}

\begin{abstract}
Abstrakt: Text se věnuje historii pobytu v př́rodě v českých zemích - zejména okamžikům, které zásadně ovlivnily dnešní pojetí výchovy v př́rodě (reprezentované zejména Prázdninovou školou Lipnice) - a využití jeho programů, postupů a metod ve výchově holistické, reflektované zážitkovou pedagogikou.
\end{abstract}

Klíčová slova: výchova v př́rodě, zážitková pedagogika, holistická výchova, pobyt v př́rodě, prázdninová pedagogika, pedagogika volného času, Prázdninová škola Lipnice, tábornická škola, Junák

Výchova v přírodě nejspíš není tématem, které by hýbalo dnešní pedagogickou veřejností, odbornou obcí a těmi, kdo projekty v přírodním prostředí připravují a uskutečňují - tím je spíše zážitková pedagogika. ${ }^{1}$ Spojení zážitková pedagogika se objevilo nedávno, někdy v počátku posledního desetiletí minulého století. Základy tohoto mladého oboru vyrostly na zkušenostech získaných s pobytem a výchovou v př́rodě. I když... známý tulák českou minulostí Petr Hora Hořejš v rozhovoru (Vaštová, 2019, s. 103) řekl, že:

zážitkovou pedagogiku spontánně zavedli ve svých tlupách neandrtálci. Ne každému, kdo se oborem zabývá, se to bude líbit, ale je to tak, protože tam ta pedagogika opravdu byla zážitkem: dones dřevo, přilož na oheň, vyhýbej se hadům, tuhle bobuli nejez, pazourek se štípe takhle a sestřička se nebije.

Že se tak dělo v př́rodě, nejspíš někde v blízkosti jeskynního příbytku (v českém prostoru mohlo jít o jeskyni Šipka nedaleko Štramberka na severní Moravě), je nasnadě.

Ivo Jirásek (2019) konstatuje:

Je nezbytné porozumět i termínům pobyt a výchova $v$ prírodè, moderní formy výchovy v př́rodě, označení intenzivní rekreační režim či prázdninová pedagogika

1 Pojem zážitkový se stal v posledních letech - ke škodě pedagogiky - bohužel poněkud módní: zážitkové je kdeco - gastronomie, dárek, pobyt, ubytování, agentura, cestovní kancelář... 
- a teprve poté, na úplném konci dlouhé vývojové linie, se objevuje termín zážitková pedagogika. Bez znalosti vývoje a jeho kořenů nemůžeme adekvátně porozumět podstatě jakéhokoliv zkoumaného fenoménu. A protože se v českém prostředí objevuje tato nálepka opravdu až počátkem 90 . let, snadno můžeme sklouznout do zdání, že dř́ivější minulost není v daném oboru důležitá a nemůže nám přinést žádné poučení.

Pokusme se porozumět tím, že se vrátíme i do dávných časů... Jaký je ten př́iběh výchovy v př́rodě, příběh v českých zemích velmi specifický, jehož první kapitoly byly psány před více než sto lety, na začátku dvacátého století, ještě za Rakouska-Uherska? Dějiny tohoto oboru byly zpracovány a podrobně popsány (např. Jirásek, 2019; Neuman \& Hanuš, 2007; Neuman, 2011).

Podobně jako Ivo Jirásek (2019) se autor přiznává, že jeho osobní zkušenost (kromě členství v turistickém oddíle v čase dětství a účasti na táborech v letech dospívání) vychází z vedení junáckého oddílu v letech 1968-1971. Zejména je však těsně propojena s legendární Lipnicí - jak v čase experimentů, tak zejména s lipnickou Prázdninovou školou (dále PŠL), a to od samého počátku její existence. Stručný historický exkurz do více než stoletého př́iběhu výchovy $\mathrm{v}$ přírodě $\mathrm{v}$ českých zemích povede $\mathrm{k}$ zastavení u čtyř milníků - klíčových momentů a událostí, které se odehrály v období posledních více než padesáti let. A nabídne tak nahlédnutí ke kořenům toho, co vedlo ke vzniku lipnické školy - a autorův pohled na její vklad do příběhu tohoto pedagogického oboru.

\section{Začátek 20. století}

Do desátých let minulého století sahá u nás tradice programů a organizací, které se věnovaly pobytu a výchově v př́rodě - skautingu (od roku 1914 Junák - český skaut) a woodcrafterské organizace Liga lesní moudrosti. V červenci 1912 roku pořádá Antonín Benjamin Svojsík - pedagog, učitel tělocviku na žižkovské reálce - nedaleko Lipnice nad Sázavou první skautský tábor.2 Stojí za to, nahlédnout do základní učebnice českých skautů té doby: A. B. Svojsík vydává svoje Základy junáctví právě v roce $1912 .{ }^{3}$ Slovník sice

A již následujícího roku poprvé ve stanech s podsadami - v unikátu, který je dodnes předmětem zájmu a obdivu skautů z celého světa.

3 Je velmi obsáhlá: má 724 stránek, na obsahu se podílely autorsky více než tři desítky významných postav - politiků, univerzitních profesorů, spisovatelů i pedagogů, mj. M. Aleš, A. Jirásek, K. V. Rais, J. Guth-Jarkovský. 
odpovídá době, ale nabízí jasnou představu o tehdejším směřování skautské výchovy a může být inspirující i dnes. Ve své předmluvě Svojsík (1912, s. 7-8) mj. uvádí:

Již několik let před tím (před návštěvou Angliev roce 1911) zabýval jsem se studiem všestranné přirozené výchovy ve volné přírodě (...) V Anglii našel jsem idylicky krásné scény ze života skautů v lesích, ušlechtilost, bezvadnost vystupování, opravdovost v každé práci, at' duševní či tělesné, horlivost v konání dobra, energie a čistá, jasná duše zírající z jejich očí, nepřipouštějící ani zdání klamu. Tot' jsou nepopíratelně skvělé výsledky silné výchovy v př́rodě, jež byla mým dávným ideálem. (...) Jak mistrně využitkováno tu chuti mládeže k dobrodružnému životu v př́rodě, jak každá hra a zdánlivě nepatrná, pro zábavu vykonávaná práce mění se ve významnou složku výchovnou!

Výchova přirozená a v př́rodě je název první z mnoha kapitol této knihy. Její autor František Drtina odkazuje na nositele idejí minulých století (Francoise Rabelaise, Jana Amose Komenského a Jeana Jacquese Rousseaua) volající po návratu k př́rodě (Svojsík, 1912, s. 15-17). Konstatuje:

V duchu velikých těchto idejí minulosti i současných reformních směrů výchovných století 20 . počíná ve skutek uváděti reformní ideje výchovné. Škola byla dosud ústavem vyučovacím - má se státi ústavem výchovným. Netoliko osvěcovati a tř́biti rozum, ale také, a především šlechtiti cit, síliti vůli; nejen dbáti duše ve smyslu moderní lásky k životu a k př́rodě, ale utužovati, síliti, krášliti tělo - tj. veliký úkol školy, jejž novým způsobem chtěji ř řšiti ústavy nové - školy výchovné na venkově.

Do těchto let je také datován počátek formování trampingu: hnutí, které je oproti skautingu a woodcraftu - neorganizované, ale jimi inspirované. Je také inspirované životem původních obyvatel Ameriky a Divokým západem - preferuje únik z měst do př́rody, kempů, později osad trampského hnutí, hnutí specificky českého (a slovenského). Je dochován doklad o založení (žrejmě první) trampské osady na Vltavě v roce 1918. Kempy a osady vznikaly na Sázavě, Berounce, v Brdech.

Pro úplnost připomeňme, že v tento čas jsou v českém prostoru na poli pobytu v př́rodě - a také turistiky - činné organizace založené již v 19. století: Sokol (jeho založení v roce 1862 bylo prvním výsledkem českého obrození v oblasti tělesné výchovy) a Klub českých turistů (1888). 


\section{První republika}

Skončila první světová válka, byla založena samostatná Republika československá. Junák - český skaut se v červnu 1919 spojil s dalšími skautskými skupinami a vznikl Svaz junáků - skautů Republiky československé, nad kterým převzal patronát sám prezident T. G. Masaryk. Mimo tento svaz působily některé další skautské skupiny, orientované politicky (např. levicoví Spartakovi skauti práce, národněsocialističtí Junáci volnosti nebo Švehlovi junáci spojení s agrární stranou). Program mírící do prrírody (turistika) najdeme i v činnosti levicově orientované Federace dělnických tělovýchovných jednot založené v roce 1921 (Koura, 2016).

Od roku 1921 u nás rozšírily své působení největší organizace mládeže na světě, YMCA a YWCA, sdružení a hnutí založené na křest’anských principech. Jsou zaměřené zejména na práci s dětmi a mládeží: aktivní trávení volného času, harmonický rozvoj osobnosti člověka - jeho ducha, duše a těla. V tomto roce bylo zřízeno tábořiště YMCA na Sázavě u Soběšína:

YMCA začala velmi rychle podnikat vše pro to, aby se z ní stal „Ráj hochů na Sázavě“, jak se mu během první republiky říkalo. Tábor patří ke kultovním místům nejen ymkařského táboření, ale můžeme říci, že svým stáŕím i organizovaného táboření na území naší republiky vůbec. (www.ymca.cz)

Rozvoji programů v př́rodě (at' už pobytových nebo výchovných) napomáhá literatura - např. česká vydání knih J. Londona a také E. T. Setona. Nejdříve vycházejí jeho povídkové knihy, ve 20 . letech potom vycházejí i romány. V několika vydáních (poprvé v roce 1925) jsou mj. vydány jak Rolf zálesák, tak Dva divoši. A připomeňme také černobílé němé, později (ve 30. letech) i zvukové filmové westerny.

K masovějšímu rozvoji trampingu dochází počátkem třicátých let, kdy se kolem tohoto fenoménu dotváří specifický subkulturní styl. Tramping začal být postupně českou společností akceptován a tolerován. Přispěla k tomu i skutečnost, že postavy trampů se začaly objevovat v literatuře a ve filmu.

Nesmí být opomenut ani vklad Eduarda Štorcha - spisovatele, autora knihy Lovci mamutů a pedagoga - právě na poli výchovy v prŕrodě. Ačkoliv nebyl učitelem tělocviku, patřil mezi průkopníky lyžování a turistiky ve škole: domyslel i výchovnou funkci lyžařských kurzů, letních táborů a exkurzí objevujících dávnou minulost a krásu př́rody (Neuman, 2011). Prioritou pro něj 
byly děti a jejich výchova, stal se také v pozdějším věku skautem. Svůj projekt Dětská farma v Praze na Libeňském ostrově, kde zřídil dětskou základnu $\mathrm{s}$ velkým hřištěm a školou $\mathrm{v}$ přírodě, založil a rozvíjel již ve 20 . letech minulého století. Výuka (docházeli sem žáci ze školy v Jindřišské ulici) - tělocvik, př́rodopis, pozemky - zde probíhala vždy tři dny v týdnu v dopoledních hodinách, odpoledne byla věnována různým aktivitám (Štorch, 1929).

Koncem 30. let vstupuje do tohoto prostoru - a dodnes jeho jméno a vliv v něm stále nacházíme - Jaroslav Foglar. Od roku 1927 vedl legendární pražskou skautskou Dvojku, zkušenosti zúročil jako redaktor časopisů pro chlapce (čtenářské kluby Mladého hlasatele) a spisovatel (1937 vycházejí Hoši od Bobří řeky a od roku 1938 začínají vycházet Rychlé šípy). Republika má za sebou 21 let demokracie. Blíží se konflikt, který zasáhne nejen Evropu.

\section{Protektorát 1939-1945, třetí republika 1945-1948, únor 1948, padesátá léta}

Po vyhlášení Protektorátu v ř́innu 1939 byly národně orientované české spolky (Junák, Sokol, YMCA i další organizace) rozpuštěny. Útočištěm jejich členů se stal Klub českých turistů - zůstal jedním z mála ohnisek národního života. Řada členů těchto spolků se zapojila do protinacistického odboje, mnoho jich zemřelo - padli v boji, byli popraveni, umučeni ve vězení nebo v koncentračních táborech.

Po skončení války v roce 1945 nastalo krátké, ani ne tříleté období nadechnutí svobody - například skauting je u nás obnoven již v květnu 1945. Hledá se podoba organizování sportovní a tělovýchovné činnosti, která ale mírí k jejímu sjednocení.

Po komunistickém převratu v únoru 1948 jsou v průběhu několika let zakázány Junák, Liga lesní moudrosti, Orel, YMCA a další organizace. Zásadní změnou, která se dotkla všech organizací, bylo sjednocování do velkých organizačních celků, které umožňovalo komunistickému režimu veškerou činnost řídit centrálně, direktivně - ve všech organizacích měl rozhodující slovo. Sokol sloužil několik let pro sjednocování sportovních a turistických svazů a klubů, které do Jednotné tělovýchovné organisace Sokol musely převést své členy i svůj majetek. Přišel čas nesvobody trvající více než 40 let. Vše - včetně výchovy - bylo podřízeno státu, vládnoucí straně, její ideologii a její kontrole. Příroda se ale ze životů nevytratila. Stále byla využívána jako prostředí pro 
uskutečňování aktivit - individuálních i organizovaných - rekreačních, sportovních, turistických, tábornických, pro pobyt v přírodě. ${ }^{4}$

Pobyt a aktivity v př́rodě najdeme od padesátých let $\mathrm{v}$ programu turistických a sportovních oddílů sdružených v již sjednocené (1957) tělovýchovné organizaci ČSTV (napřr. Turistické oddíly mládeže). Celoroční činnost včetně táborů a soustředění nabízely domy pionýrů a mládeže a od 60. let také specifické pionýrské oddíly - tábornické, věnující se především tábornictví a turistice. Jejich vedoucí často čerpali ze svých dřívějších zkušeností v junáckých oddílech. Ve druhé polovině 50. let se usnesením vlády pořádání letních táborů pro děti začíná věnovat odborová organizace ROH. Ta získala po válce (at' již v důsledku odsunu německých obyvatel státu nebo prostřednictvím znárodňovacích akcí) celou řadu objektů, jež využívala k pořádání rekreačních pobytů (některé dala do správy jednotlivým podnikům coby závodní zotavovny). Pionýrské tábory ROH neměly sloužit pouze k rekreaci a utužení zdraví dětí, ale měly děti vést rovněž k větší družnosti, dobrovolné kázni, samostatnosti, rozvíjení iniciativy a tvořivosti, učit se úctě k práci a socialistickému vlastnictví (Fischerová, 1957).

Zapomenout nesmíme na školy: na vysokých školách jsou pořádány kurzy aktivit v přírodě, kterým se věnují i sportovní oddíly vysokoškolských tělovýchovných jednot (turistika, horolezectví, lyžování, kanoistika). Střední školy mají v programu kurzy lyžování, základní školy kurzy lyžování a školy v př́írodě. Najdeme zde i výchovné prvky: na jedné straně reprezentující oficiální ideologii, na straně druhé i takové, které vycházejí z tradic výchovy.

Zpětný pohled na oficiální pojetí výchovy v této době nabízí Pavelková (2015, s. 111-122):

Jedním z nejdůležitějších komunistických hesel byla převýchova jedince v nového člověka, který bude uplatňovat novou morálku, jež je nutná pro přechod k ideálnímu komunismu. Člověk není schopen vlastní iniciativy a za nic nenese osobní zodpovědnost. Hlavní výchovnou metodou byla kolektivní výchova, která se snažila co nejvíce potlačit přirozenou spontaneitu jedince.

Tématu výchovy „nového socialistického člověka“ se věnuje také Nečasová (2018): tento „nový člověk“ se má stát vzorem hodným následování a symbolem optimistické budoucnosti.

4 Ne vždy legálních: některé junácké oddíly se uchýlily do ilegality, tramping byl režimem nechtěný a trampové bezpečnostními složkami státu pronásledovaní... 


\section{4 Šedesátá léta}

Šedesátá léta se v Československu vyznačovala postupným uvolňováním společnosti v politické a kulturní oblasti. Na podzim roku 1963 (společnost má za sebou zatím 15 let vlády jedné strany, KSČ) - paradoxně a nečekaně uvnitř tehdejší jediné, jednotné organizace mládeže ČSM a navzdory poměrně tuhému politickému režimu (do pražského jara 1968 zůstávají ještě více než čtyři roky) - se události v oblasti pobytu $\mathrm{v}$ prŕrodě daly do pohybu.

\section{Milník první - 1964: Tábornická škola}

Blíží se první klíčový okamžik novodobých dějin pobytu a výchovy v přírodě, který ovlivní tento obor na mnoho let. Cesta k němu ale nebyla jednoduchá. Vlastimil Snopek (1969, s. 7-8) popisuje tehdejší události takto:

Koncem roku 1963 projednává př́slušný tajemník ČSM návrh na zřízení školy v př́rodě, lišící se podstatně od dosavadního pojetí turistiky. Jejím cílem bylo hledat, rozvíjet a zavádět nové, pestré, romantické a přitažlivé formy práce mezi mládeží. Pro odlišné pojetí navržené školy od turistiky byl zaveden pojem tábornická škola a tábornictví. V návrhu školy se objevily osvědčené zálesácké a sportovní prvky dřívěǰ̌ích organizací lesní moudrosti, Junáka, Spartakových skautů práce a historického trampského hnutí.

V létě následujícího roku se na Sluneční pasece pod Křemešníkem u Pelhřimova odehrála - jak vzpomíná Snopek (1969, s. 8) - historicky první

těžce vybojovaná tábornická škola: Tábornická škola dýchá prostředím románů Jaroslava Foglara. (...) Otevřené a svobodné diskuse celého kolektivu školy se vedou s fanatickou vášnivostí i dlouho do nocí. Opět se leskne barevný totem ve světle táborového ohně, který je po mnoha letech prvním světlem v temnotě udušených tužeb a představ mládí toužícího po rozletu.

Sluneční paseka sloužila jako místo pořádání tábornických škol i v následujících letech.

Na jaře roku 1968 byl obnoven Junák, Liga lesní moudrosti, Sokol. Založena byla Česká tábornická unie, navazující na ideje woodcraftu, trampingu a tábornických škol - a vznikly další organizace. Renesanci programů v př́rodě napomohla skutečnost, že v průběhu 60. let začaly opět vycházet knihy Foglara, Londona a Setona. V létě roku 1968 byly pořádány - po dvaceti letech - junácké tábory. Po násilném potlačení pražského jara spojeneckými 
vojsky Varšavské smlouvy v srpnu roku 1968 nastal čas postupné normalizace - organizace se musely přihlásit $\mathrm{k}$ výchově v socialistickém duchu. ${ }^{5}$

\section{$5 \quad$ Sedmdesátá léta}

V roce 1970 byla činnost skautské i dalších sedmnácti organizací dětí nebo mládeže, založených či obnovených v roce 1968 a 1969, zastavena. Po krátkých dvou letech se vrací časy jednotné organizace dětí a mládeže - Pionýra a SSM. Jejím hlavním úkolem bylo ovládnout (znormalizovat) vysoké a střední školy, potlačovat svobodu názorů mladých lidí - cílem byla výchova mládeže v duchu marxismu-leninismu. Jak měla vypadat? Vrat'me se do slovníku těch časů (Kujal, 1973, s. 675-701):

Zvláštní pozornost se věnuje komunistické výchově jako jednotě výchovy a vzdělání. Výchova se chápe jako systém osvojovaných a osvojených vlastností, jako je vědecký světový názor jednotlivce, jeho komunistická morálka, rozvinuté estetické vnímání a socialistický vkus, socialistické pracovní kvality a tělesná kultura socialistického člověka.

\section{Milník druhý - 1970: Středisko Lipnice}

Na přelomu 60. a 70. let nastává druhý klíčový okamžik příběhu: tím je výstavba střediska pod Lipnicí nad Sázavou, u zatopeného lomu Na Hřebenech. Bylo otevřeno v červnu roku 1970 a dá se - při ohlédnutí do jeho padesátileté historie - $\mathrm{s}$ jistotou ř́ci, že se tak stalo ve správnou chvíli. V oboru pobytu a výchovy v př́rodě sehrálo zcela jedinečnou roli a stalo se legendou. Petr Hora o „Lipnici“ později v časopise Mladý svět napsal mj.: „Uprostřed Evropy země, uprostřed země les, uprostřed lesa kopeček, uprostřed kopce skála a pod ní zatopený lom, myslím, že důl na radost, údiv a romantiku. Nádhera. Př́roda jak vysněná." (Hora, 1984a, s. 11).

A redaktor téhož časopisu, Zdeněk Šálek (1988), v jedné ze svých lipnických reportáži píše: „Je to místo, jež dělá z lidí obyčejných lidi neobyčejné.“

Pro zajímavost nahlédněme do osnov letní ústřední tábornické školy z této doby, z roku 1971 (Letní..., 1971). Zkoušky byly z následujících předmětů: test tělesné zdatnosti, prusíkování práce s lanem, lasování, lukostřelba, praxe hry - obsahové formy letního pobytu v př́rodě, první pomoc a hygiena, topografie, orientace, uzlování, plavání, organizace pobytu v př́rodě, psychologie, rétorika, stručná historie tábornictví a jeho předchůdců, zvyklosti, vaření, judo - základy sebeobrany, test znalostí z př́rody. 
Co to je za místo? Pozoruhodná stavba vystavěná na břehu zatopeného lomu, která chce být a také je v souladu s krajinou a krajem (základními materiály jsou kámen a dřevo), stavba neobvyklá svým půdorysem, tvarem, interiérem. Nad jezerem v lomu se tyčí stěna výšky 10 metrů: to bylo jeviště zásadních „lipnických“ programů. A k tomu nabídka okolí bližšího i vzdálenějšího: členitý terén s lesy, hustníky, pasekami, roklinami, cestami a pěšinami, dalšími zatopenými lomy, rybníky. To vše nabízelo výzvy, inspiraci (podrobněji Gintel, 2019; Holec, 2007). Architekt Vaculík, autor stavby, pravděpodobně netušil, jak přesně se setká jeho realizovaná architektonická vize s potřebami akcí, které zde budou pořádány. Anebo naopak: její pořadatelé - instruktoři využívali všech možností, které jim stavba a její okolí nabídla, pro dosažení maximálního účinku svých akcí. Lipnické středisko bylo otevřeno ve chvíli, kdy společnost po srpnu 1968 postupně upadala v nastupující normalizaci do letargie.

Dá se říci, že v tento čas, na průsečíku příběhu lidí, kteří cítili a věřili, že v přírodním prostředí ještě může zůstat nějaký svobodný prostor a př́běhu právě otevřeného lipnického střediska, se dějiny pobytu a výchovy v př́rodě u nás vydaly po zcela mimořádné trajektorii. Začíná se psát kapitola, kterou můžeme nazvat novověkem výchovy v př́rodě v českých zemích.

Kdo byli ti lidé? - Zde krátké ohlédnutí (Stránský st., 2010, s. 39):

Byla ustavena Metodická rada pro pobyt $\mathrm{v}$ př́rodě ČÚV SSM, která i nadále zajištovala pořádání tábornických škol, a to letních, zimních, vodáckých a vysokohorských. (...) Mezi členy Metodické rady přešla řada bývalých členů České tábornické unie, kteří sice nepodporovali vznik nové jednotné organizace, ale považovali zánik tábornictví za velkou škodu. Rada v první řadě podporovala a rozvíjela experimentální akce, které využívaly různých forem zážitkové pedagogiky.

Začátkem 70. let běží celoročně program nabízený instruktorským sborem napojeným na metodickou radu pro pobyt v př́rodě: akce turistické, zimní, cyklistické, vodácké, vysokohorské, sportovní a další, inzerované v pravidelné rubrice Táborový oheň v časopise Mladý svět (rubrika vycházela od roku 1967, původně byla určená pro trampy). Nastává ale také čas hledání, vyvolaný potřebou nalézt program pro nové, právě otevřené středisko u lipnického lomu. Allan Gintel, který Metodickou radu pro pobyt v př́rodě vedl, vzpomíná (Jirásek, 2013, s. 42): „Dostal jsem nabídku, vymyslet pro tento 
objekt nový a pro mladé lidi přitažlivý program. Zůstal totiž po všech těch politických změnách prázdný, chyběli organizátoři a všeobecně přijatelná idea. Taková nabídka se neodmítá." A tak pro Lipnici vznikl Pokus pro dvacet, následuje Projekt prima prázdnin a zejména pět ročníků dnes již legendárního projektu Gymnasion. Ten jeho autor (Gintel, 1980, s. 8-9) charakterizuje:

Režie projektu, inspirovaná antickým Gymnasionem, se nespokojuje jen se stř́iáním činností pohybového charakteru s činnostmi, které umožňují aktivní přijímání nebo i aktivní provozování umění, ale jde mnohem dál: zařazuje diskuse, rozpravy o filosofických a jiných otázkách, přednášky... Jde jí [režii projektu] o kultivaci účastníkủ ve smyslu aktivního př́stupu k celému životnímu prostředí a mikroprostředí člověka.

Na historickém fundamentu pobytu v př́rodě (skauting, lesní moudrost, turistika, táboření, sporty $\mathrm{v}$ př́ŕrodě), který byl stále využíván, se podařilo na Lipnici postupně hledat a rozvíjet programy a metody s podstatně větším dosahem a dopadem. Zásadní změna: v programu začínají hrát významnou roli hry - a nejde už o hry pro věk dětský, ale hry dospělého věku. Skutečnost, že I dospělí si mohou hrát, potvrzuje nejen Eduard Bakalář se svojí knihou tohoto názvu (vydanou v roce 1976), ale i program experimentálních akcí. Inspirace pro hry a jejich témata se hledala ve skautských příručkách, herních publikacích Miloše Zapletala, Foglarovi. Skvělé inspirace nabízelo samotné lipnické prostředí (legendární Finská stezka). A dařilo se je nacházet například i ve světě filmu (Koně se také stř́lejí). Do programů se dostávají - kromě sportů v př́rodě a her (nejen pohybových, také diskusních, málostrukturovaných aj.) - například také programy vyžadující tvořivý přístup a poslechové vzdělávací pořady. Tento programový mix se stává základní charakteristikou české metody pobytu (později výchovy) v př́rodě.

Pokud jde o ideové zdroje, hledaly se $\mathrm{v}$ dávném věku - zejména $\mathrm{v}$ antice. Starořecká kalokagáthia jako idea harmonie těla a duše, jako jednota krásy a dobra, na kterou se organizátoři programů $v$ té době velmi často odvolávali, v sobě ukrývá nejen ideál, ale i jasný výchovný záměr - byt' se o výchově explicitně ještě nehovořilo a nepsalo. Hledáním, zkoušením nového, ověřováním, zpracováním a popisováním vlastních zkušeností, jejich rozborem se v těchto letech experimentování docházelo k dalšímu stupni poznání - pobyt v přírodě v tomto „lipnickém“ pojetí dostal své pojmenování, které jej má odlišit od pobytové klasiky: moderní formy pobytu v př́rodě. ${ }^{6}$

6 Hodná zaznamenání je i jedna zdánlivě nesouvisející kapitola z dějin české hudby, která významnou měrou zasáhla do podoby českého pojetí pobytu a výchovy $\mathrm{v}$ př́rodě. Od 


\section{Milník třetí - 1977: Prázdninová škola}

Po sedmi letech experimentování (posledním experimentem byl tř́letý projekt Šance) se v březnu 1977 ve Ždáru nad Sázavou konal seminář věnovaný moderním formám pobytu v přírodě. Mezi „schválenými opatřeními“ bylo jedno zásadní: „zř́́dit Prázdninovou školu ČÚV SSM, která by sloužila doškolování $\mathrm{v}$ oblasti moderních forem pobytu v přírodě a $\mathrm{v}$ oblasti pedagogiky volného času“ (Metodické listy, 1977, s. 18).

Zdeněk Šálek (1983, s. 6) v úvodu publikace Dones oheň a zvítězíš píše:

SSM nabídl mládeži po letech experimentů a bojů s konzervatismem bohatý program, jak prožít volný čas především v přírodě, kam se člověk musí vracet. Objevil a vyzkoušel dnes už známé „moderní formy pobytu v přírodě“, jejichž principem je souběžná zkouška ducha i těla, a ověřil desítky her k tomuto účelu zaměřených. Známými se staly i pojmy Sluneční paseka a Lipnice, tedy místa, kde se zrodila nová, moderní náplň turistiky, táboření a prázdninových pobytů.

Nezapomeňme také na Hnutí Brontosaurus, jehož kořeny sahají do této doby - konkrétně do roku 1974, do časopisu Mladý svět a k jeho redaktorovi Josefu Velkovi. Hnutí působilo v oblasti ochrany přírody, brzy po založení získalo velkou popularitu, již v prvním roce existence byly pořádány víkendové i prázdninové akce v prírodě (Prázdniny s Brontosaurem). Vzhledem $\mathrm{k}$ velkému zájmu původně jednoroční program pokračoval i v dalších letech (a existuje do dnešní doby).

20. a 30. let minulého století do něj vstoupila zpívaná píseň a stala se jeho součástí. Díky trampingu, skautingu a Lize lesní moudrosti tak vzniká specifické odvětví českého folku, které získalo označení trampská píseň. Do repertoáru osad, oddílů a táborů se tehdy dostávaly tzv. kovbojské písně - at' už původní americké (i díky gramodeskám, rozhlasu a zvukovému filmu) nebo původní české, kterým se věnovaly trampské osady a jejich sbory. Napomáhala tomu velmi populární sešitková dvoulistová vydání těchto písní.

A od 60. let se tento úkaz vrací. I díky společenskému pohybu a mírným politickým změnám období před rokem 1968. K trampské klasice se přidávají písničky $\mathrm{V}+\mathrm{W}, \mathrm{S}+\breve{S}$, české verze původních amerických lidových písní a také spirituálů (již jsou k dispozici i původní nahrávky) - a v dalších desetiletích se repertoáry obohacují o písně původní, českých autorů a skupin, kteří se věnovali trampské písni, folku, country a bluegrassu. Stačí připomenout fenomén zvaný Porta. (Legenda české trampské písně - Wabi Ryvola - byl mezi těmi, kdo se na Sluneční pasece zúčastnil tábornické školy, dlouhé sedmnáct dnů.) To vše bylo bohatým zdrojem, ze kterého čerpaly (a snad ještě čerpají) repertoáry oddílů, klubů, osad, neformálních skupin, táborů. 


\section{Osmdesátá a devadesátá léta}

Po letech experimentování a prvních ročnících Prázdninové školy dochází organizátoři kurzů Prázdninové školy k poznání, že lipnické kurzy v sobě mají ukryt - nad rámec běžného pobytu - užitečný potenciál: obnova tvořivých sil (rekreace) se jevila jako docela akceptovatelné pojmenování skutečnosti (pojem „výchova“ byl stále ještě poněkud tabu). - Do života je uveden nový pojem: intenzivní rekreační režim. V časopise Mladý svět píše Petr Hora (1984a):

Frekventant Prázdninové školy zjistí, jak chutnají prázdniny ozdobené šlehačkou činorodosti. Vesměs konstatuje, že nad takové není. A o tohle poznání na Lipnici jde. Lidé neodjíždějí s glejtem o absolutoriu a získané kvalifikaci, nýbrž s inspirací. Otestovali své možnosti, zdolali programový nápor, jemuž zdejší pedagogovévrstevníci ř́kají intenzivní režim, a vracejí se domů s pocity mimořádného zážitku.

(Začíná se zkoumat role zážitku.) Téhož roku vycházejí pod vedením mistra slova Petra Hory Hořejše (1984b) Prázdniny se šlehačkou - dílo (velmi dobře čtivé), které přináší představu o přípravě a pojetí lipnických kurzů v té době.

Jak to bylo s výchovou? Dá se s jistotou říci, že téma výchovy v př́rodě se dostává do popředí zájmu někdy v polovině 80 . let. Po semináři v Luhačovicích v roce 1985 se do úvah (i do života lipnické školy) dostává také téma dobrodružné výchovy v př́rodě. Inspirací jsou zejména expedice Outward Bound, cílem historicky první výpravy je v roce 1988 Bajkal.

Při desetiletém výročí Prázdninové školy píše Zdeněk Šálek (1988) v časopise Mladý svět:

Nepochybně základním cílem této zcela výjimečné školy, jak ji s úctou nazývají psychologové, pedagogové a sociologové, je rozšíření běžné rekreace v př́rodě o výchovný efekt. Snaha navést účastníky na vysoce aktivní styl života, donutit je $\mathrm{k}$ intenzivnímu tělesnému i duševnímu pohybu, přivést je $\mathrm{k}$ cílevědomému sebevzdělávání, $\mathrm{k}$ přirozené potřebě udělat něco pro druhé a $\mathrm{k}$ vnitřní potřebě pracovat sám na sobě.

Začalo se pracovat s pojmem prázdninová pedagogika (zkušenosti jsou z kurzů v čase prázdnin) nebo - a to už nabízelo univerzálnější časový prostor s pojmem pedagogika volného času. V ř́jnu 1989 je u přehrady Seč pořádán mezinárodní seminář Volný čas a výchova mládeže v př́rodě.

Do př́ípravy i uvádění lipnických projektů se v průběhu osmdesátých let dostávají pojmy ze světa divadla: dramaturgie, scénář, režie, produkce. Mají 
jeden důležitý cíl: najít takové programy, jejich skladbu (pro každý jeden den i pro celý projekt) a jejich podobu uvedení, které dosáhnou maximálního účinku - nejen rekreačního, ale zejména výchovného a vzdělávacího. Z dramaturgie se stává významný obor výchovy v přírodě.

\section{Milník čtvrtý - 1989: listopad 1989}

Čtvrtým důležitým okamžikem byl (a to nejen pro obor pobytu a výchovy v přírodě) listopad 1989 a vše, co nabídla svoboda následujících let.

Změny zasahují všechny sféry života společnosti - politickou, ekonomickou, společenskou - a mění se také styl života. Dochází ke změně využívání volného času - nabídka služeb a vybavení pro pobyt a aktivity v prŕírodě vychází vstř́íc rostoucí společenské poptávce. Vychází jí vstříc nabídka programů cestovních kanceláří a agentur a také programy individuální, rodinné i akcí neformálních skupin. Do př́rody tak mírí stále více turistů, cyklistů, lyžařů, vodáků - a to nejen organizovaných. Polistopadová svoboda umožňuje uskutečnění plánů, programů a snů také v zahraničních lokalitách.

A přírodní prostředí ve větší míře využívají ke své činnosti i spolky a sdružení ustavené na novém právu - právu na svobodné sdružování. Jestliže do listopadu se projektům výchovy $\mathrm{v}$ př́rodě věnovalo jen několik organizací (Prázdninová škola, Hnutí Brontosaurus, Instruktoři Brno, Pionýr - tábornické oddíly, ČSOP), tak po listopadu se k nim přidávají další: a to jak organizace obnovené - Junák, YMCA, YWCA, Česká tábornická unie, Sokol, Liga lesní moudrosti, Sdružení přátel Jaroslava Foglara - tak nově založené, např. DUHA, Hnutí Go!, Asociace turistických oddílů mládeže, Agentura Hobit, ekologické organizace (např. Sdružení Tereza) a spolky křestanské (např. Salesiánské hnutí mládeže).

Významné místo v oboru zaujímá stále lipnická Prázdninová škola - ta se na jaře 1990 stala občanským sdružením. Kontakty s mezinárodní organizací Outward Bound, působící na všech pěti kontinentech (a následné členství PŠL $\mathrm{v}$ této organizaci) a stáže a pobyty zejména $\mathrm{v}$ britských centrech začátkem 90. let přinesly do „lipnických“ projektů řadu zkušeností: programových (seznamovací a rozehřívací hry, hry podporující skupinovou dynamiku, lanové překážky - vysoké, ale zejména nízké), metodických (standardy bezpečnosti programů, zdravotní zabezpečení) a také pedagogických (práce se zážitkem - review). Užitek přinesly první poznatky o kurzech pro firemní klientelu, pro hendikepované aj. Mezi významné osobnosti, jejichž jméno je spojeno 
s výchovou v př́rodě, vstupuje jméno původem německého, později anglického pedagoga Kurta Hahna, jednoho ze zakladatelů organizace Outward Bound a zakladatele několika vzdělávacích institucí a škol po celém světě.

Lipnické projekty se v té době také začínají věnovat roli, významu a funkci zážitku v programu kurzu. Zážitek se jistě objevoval i v počátcích dávné historie programů pobytových akcí - vzpomeňme např. skautské obřady a rituály - slavnostní nástup, slib, obřad přijímání nových členů, společný zpěv hymny (i oddílové), dobrodružné programy (stezka odvahy...), plnění zkoušek (např̀ tři orlí péra). Projekty nabízí široké spektrum: zážitek z překonání překážek, výzev, nezdarů, bolesti. Zážitek (velmi důležitý) spojený s překonáním sebe sama. Zážitek z vítězství, úspěchu, z „patnácti minut slávy“, která je provází. Také ale z nezdaru, neúspěchu, prohry. Zážitek ze setkání - s lidmi, myšlenkami, zkušenostmi druhých. Zážitek ze spolupráce. Z prostředí, jeho atmosféry, $\mathrm{z}$ obřadů. Stále také zážitek $\mathrm{z}$ bytí $\mathrm{v}$ př́rodě, $\mathrm{z}$ jejích proměn $\mathrm{v}$ průběhu roku i v průběhu dne (rozednění, západ slunce, tma). Někdy ne vždy př́ijemný zážitek ze setkání se živly (déšt', vítr, zima, sníh). Radost, euforie, důvěra, očekávání, překvapení, obava, strach, napětí, rozpaky, smutek, nadšení - to jsou některé z pocitů, které zážitky provázejí. Individuální, velmi často ale také sdílené.

Poznatky získané po roce 1989 v zahraničí (Outward Bound) vedly k tomu, že se se zážitky začalo vědomě pracovat. Jejich rozbor (review, reflexe), uskutečněný bezprostředně po programu, nabízí možnost zpracování zážitků do podoby zkušenosti, individuální i skupinové, která je využitelná v dalším programu i v dalším životě. Vedení rozborů není jednoduché - aby přinesly potřebný užitek, vyžadují jistou odbornou výbavu a zkušenost pedagoga: nabízí ale přidanou hodnotu, pokud jde o „osobní zisk“ účastníka projektu. Rozbor po programu je „královská disciplína“ instruktora, lektora (Svatoš, 2020).

\section{Počátek 21. století: patnáct pohledů na českou metodu PŠL}

Kam pokročilo, respektive jak se změnilo za uplynulé půlstoletí české pojetí výchovy v přírodě? Při vší úctě k dalším spolkům, sdružením a organizacím na tomto poli působícím vnímám lipnickou Prázdninovou školu jako reprezentanta českého pojetí výchovy $\mathrm{v}$ př́rodě, vzhledem $\mathrm{k}$ jejímu zásadnímu vkladu do oboru v průběhu více než 40 let její existence. Pokusím se o rekapitulaci tohoto vkladu. 
1) Projekty pořádané PŠL vykročily od programů a metod pro věk dětský (kterému zejména je věnován výchovný program skautingu) k programům a metodám určených starším věkovým kategoriím - v počátku určeným věku dospívání a věku mladé dospělosti. Miloš Zapletal před lety napsal (archiv autora, 1990):

Zabývám se skautskou výchovou již od roku 1949. Mám poměrně široký a dlouholetý kontakt se světem, se skauty z různých evropských zemí i v Americe, $\mathrm{v}$ mé knihovně je bohatá odborná literatura $\mathrm{z}$ celého světa. A přece jsem nenašel nikde tak dokonale propracovaný výchovný program pro mladé lidi, kteří stojí na prahu dospělosti, jako ten, který vytvořila lipnická Prázdninová škola. Viděl jsem intenzivní program pro věkovou kategorii, se kterou si téměř nikdo na světě neví rady - mladé lidi od 15 do 25 let - a že ten program dokázal téměř bez výjimky všechny účastníky strhnout.

2) Zásadním užitkem, který přineslo hledání programu pro akce pobytu $\mathrm{v}$ prrírodě v posledních desetiletích minulého století, bylo, že na kurzech PŠL byla vytvořena, uvedena a ověřena řada nových herních programů, pro které platí, že jde o hry dospělého věku. Hra se stala a je jedním ze základních programových dramaturgických kamenů každého projektu. Knižně vydané hry (je jich několik stovek) ve čtyřech dílech Zlatého fondu her (Hilská, 2013; Hrkal \& Hanuš, 1998; Zapletal, 1990; Zounková, 2007) jsou toho dobrým dokladem.

3) Kromě programů a metod pro věk dospívání a mladé dospělosti, které byly v centru zájmu PŠL před listopadem 1989, ověřila PŠL v dalších letech programy a metody projektů na kurzech pro další skupiny účastníků: nastupující středoškoláky (adaptační kurzy), integrující hendikepované a zdravé, věkovou kategorii 50+, rodiče s dětmi a další. Základem každého ročníku „autorských kurzů“ PŠL (chystaných dobrovolníky) jsou kurzy pobytové $\mathrm{v}$ čase léta. $\mathrm{V}$ nabídce najdeme ale také kursy expediční zimní (legendární Životje gotickej pes, pořádaný v extrémních podmínkách ruské Altaje), kurzy na moři (mořské kajaky, velké jachty). PŠL ověřila a nabízí dnes svoje kurzy také pro člověka dospělého, který chce svému životu nabídnout nové podněty a inspirace. Instruktoři hledají pro svoje kurzy a jejich dramaturgii nová témata, která je často mohou přivést a přivádějí k novým programům.

4) O zkušenosti (v prvé řadě o hry a další programy) PŠL je brzy zájem v dalších organizacích, zabývajících se výchovou v přírodě. Miloš Zapletal napsal (archiv autora, 1990): 
Sledoval jsem několik let činnost lipnické Prázdninové školy a došel jsem $\mathrm{k}$ přesvědčení, že se vám podařilo na vašich kurzech vytvořit téměř ideální typ roverského programu. Byli bychom rádi, kdyby Prázdninová škola navázala spolupráci se skautským hnutím a poskytla nám své programové a metodické zkušenosti. Věřím, že by společné úsilí brzy přineslo bohaté plody - zejména při mravní výchově mladé generace.

5) Lipnická metoda získává po listopadu 1989 také první hodnocení z řad odborníků. Psycholog Vladimír Smékal v záŕí 1991 mj. napsal (Holec, 1994, s. 142):

Myslím, že právě dnes, v období rodící se demokracie, by měly být zkušenosti Prázdninové školy zpracovávány a popularizovány, a to nejen amatéry a nadšenci, ale že by měly být studovány i na pedagogických pracovištích, nebot' výchovný systém, který Prázdninová škola vytvořila, může být významnou pomocí v úsilí o obnovu mravních hodnot a kultury osobnosti mladých lidí.

A psycholog Václav Břicháček (1992, s. 4) v následujícím roce napsal:

Jsem přesvědčen, že na Lipnici vznikla jedna „malinká univerzita“. V obtížných podmínkách a navzdory moci tu vznikla škola. Škola všestranné výchovy, oddělená od oficiálních škol i od hlásané pedagogické teorie. (...) Vzniklo dílo, které řadím do dějin české duchovní výchovy - i když si to asi jeho tvưrci neuvědomovali a asi by toto tvrzení odmítali jako velká slova. Vnější pozorovatel - a nejsem sám - však je o tom přesvědčen.

6) V 90. letech kurzy PŠL opustily Lipnici, prostředí s výjimečným geniem loci (některé kurzy se na toto místo vracejí). V této souvislosti si připomeňme význam tohoto místa (Jirásek, 2013, s. 42): „Projekty, které vznikly na Lipnici, nepochybně vejdou do historie pedagogiky, jež zde byla v lecčems objevná, riskantní, nastolující různé otázky." Skutečnost, že Prázdninová škola opustila lipnické středisko (vlastníkem se stala Česká tábornická unie), měla jeden užitečný důsledek: potvrdilo se, že její metoda je, pokud jde o prostředí, použitelná univerzálně (kolikrát instruktoři PŠL slýchávali: „Vám se to tam, u toho lomu, dělá!“). Zkušenost kurzů Prázdninové školy je následující: přírodní prostředí musí splňovat určité požadavky na kvalitu - ta hraje zásadní roli. Není jen kulisou, naopak, je samo o sobě zdrojem výzev, nabízí přirozené překážky k překonávání, situace k řešení - a na druhé straně místa k zastavení, prodlení, rozjímání. Nabízí přirozenost - a tím i návrat k př́rodě, k podstatě lidského bytí, k jeho chápání. Je místem, kde hledáme a často můžeme najít orientaci - nejen v terénu, 
ale i v životě. Které nabízí poznání sebe sama, své role v životě, svého poslání. Pro jakékoli místo, které vybereme k pořádání svého projektu, ale platí: „V době přípravy kurzu instruktor obhlíží nové místo, čerpá, čenichá, co se v něm skrývá a jaké má možnosti a potenciál.“ (Halada, 2010, s. 40).

7) Zkušenosti z kurzů PŠL posloužily jako významné východisko pro úvahy o roli zážitku, prožitku, jeho vlivu na účinnost programů a celých projektů - tedy východisko úvah o prázdninové pedagogice, později pedagogice volného času a dnes zážitkové pedagogice. Tento pojem se začíná užívat v posledním desetiletí minulého století. Ve studijních textech PŠL z poloviny 90. let (archiv autora) najdeme tehdejší definici:

Výchova prožitkem (prožitková pedagogika) je výchovná metoda vycházející ze skutečnosti, že účinnost výchovy vzrůstá, je-li opřena o silný, intenzivní, autentický zážitek: zážitek z překonávání překážek i sebe sama, zážitek z tvoření, ze spolupráce s druhými, z kontaktu s př́rodou.

Potvrzuje to Václav Břicháček, český psycholog, vysokoškolský učitel a dlouholetý skaut, v letech 1989-1992 náčelník Junáka; v rozhovoru (Břicháček, 1997) mj. řekl:

Prázdninová škola vytvořila systém výchovy dospívajících a mladých dospělých postavený na výchově prožitkem, tzn. zaživání nezvyklých událostí, neobvyklých situací a jejich zvládání. Při tom člověk zjištuje, jaké síly, o kterých mnohdy neví, v sobě má.

8) Programy a metody zážitkové pedagogiky vycházející z tradice pobytu a výchovy v př́rodě a obohacené o zkušenosti z prázdninových projektů, zejména lipnické Prázdninové školy, vykročily z prostředí přírody a z časů prázdnin a volného času: programy a metody jsou využitelné a využívané univerzálněji - v neziskovém sektoru, ve školství, ve světě podnikání. Se zážitkem se začalo vědomě pracovat univerzálněji jako s výchovným a vzdělávacím nástrojem. Pokud hovoříme o lipnické metodě, jejím základním nástrojem je dramaturgie.

9) Zkušenosti vstoupily také „in-door“, do místnosti: došlo se k poznání, že zážitek je využitelný nejen v situacích a programech, které uvádíme v přírodním prostředí, ale emoce (a tím i zážitky) mohou vyvolat i programy „V místnosti“ - kvalita, atmosféra tohoto prostoru je ale velmi důležitá. A ke zvážení a k užitku může být využití jednodušších programů, původně 
určených pro „out-door“, i v tomto vnitřním prostředí - případně jejich užití „near-door“ (Svatoš, 2020).

10) Zkušenosti PŠL z výchovy v přírodě vstoupily do světa profesního: používají se na kurzech firemního vzdělávání, při tréningu dovedností a budování týmů. ${ }^{7}$ Historicky první profesionální společností, která se věnovala pořádáním kurzů pro sektor firem, byla Česká cesta - společnost založená v roce 1993 právě Prázdninovou školou Lipnice.

11) Zážitek (a zážitková pedagogika) vstoupil do prostředí školního: školy (zejména střední) začaly poptávat nebo samy pořádat kurzy (dostaly název adaptační) pro nastupující studenty a (školy základní) moderněji pojaté školy v př́rodě. A jsou patrné a potěšitelné snahy pracovat se zážitkem i ve vyučování - na zážitku je obvykle postavena projektová výuka. Martina Skalková, učitelka češtiny ze základní školy v podkrkonošské vsi Lánov, říká (Třešňák, 2020): „Abych u dnešních dětí mohla konkurovat Instagramu, Facebooku nebo WhatsAppu, musím jim nabídnout stejně intenzivní sdílený zážitek," když komentuje svoji pedagogickou práci připomínající na první pohled zkoušku školního divadelního souboru.

12) Výchovu v přírodě najdeme dnes v osnovách tělovýchovných fakult vysokých škol, např. FTVS UK Praha a FTK UP Olomouc. Aktivity v př́rodě či výchova v přírodě (později také zážitková pedagogika) se dostávají do studijních programů fakult i na dalších univerzitách. Jsou součástí nejen studia tělesné výchovy, rekreologie, ale i pedagogiky volného času (Neuman, 2000).

13) Sama PŠL je školou nikoli pouze v čase prázdnin, kdy předává svoje zkušenosti (nejen) prostřednictvím zážitku na svých autorských kurzech, ale i dalšími cestami. Vyučuje o zážitkové pedagogice a projektové výuce na kurzech pro pedagogy základních škol. Projekty jsou zaměřeny na rozvíjení klíčových kompetencí, na posílení vztahů a spolupráce ve sborovně nebo na získávání nových dovedností užitečných v každodenní učitelské práci. A nabízí kurzy i pro studenty a žáky, připravené na míru podle přání a potřeb školy a konkrétní skupiny (třídy). Podobná nabídka je otevřena i pro neziskové organizace. V neposlední řadě již několik let nabízí certifikovaný výcvik: soubor pěti navazujících metodických kurzů,

Jako firmu zde můžeme chápat nejen firmu obchodní, ale také např. školu nebo neziskovou organizaci. 
které účastníky provedou metodou zážitkové pedagogiky - od teoretické př́ípravy akcí až po trénink reálné práce se skupinou (Drahanská, 2020).

14) „Lipnická“ metoda byla a je Prázdninovou školou exportována do zahraničí - jak prostřednictvím účastníků mezinárodních kurzů pořádaných v ČR, tak pořádáním kurzů, které si u ní objednávají národní organizace - např. Outward Bound z Austrálie a Hongkongu. Richard Alexander (1991) z britského centra Outward Bound v Eskdale napsal:

Kurzy Prázdninové školy mají širší záběr než kurzy Outward Bound - od programů v př́rodě přes hudbu, drama, improvizace až k dolování skrytých rezerv a možností účastníků. Nabízejí tvořivý program, který dovoluje účastníkủm zazářit, psychicky i sociálně se rozvíjet a užít si spoustu legrace. Některé z programů byly pouze kostrou, myšlenkou, kterou musela skupina rozvíjet. Výsledek nebyl zaručen, ale lidem bylo umožněno ukázat, co v nich je, a nakonec to vždycky zvládli. To dávalo kurzu zvláštní vůni. Svoji roli hrál i prvek přátelského soutěžení při některých sportovně zaměřených aktivitách, tedy něco, co OB nechává v pozadí. Neř́íkám, která varianta je lepší - pouze popisuji, co jsem odpozoroval.

V roce 2004 vychází v britském nakladatelství Gower publikace (Martin et al., 2004), za kterou stojí Andy Martin z Massey University na Novém Zélandu. Ve spolupráci s instruktory PŠL v ní zpracoval své zkušenosti z kurzů PŠL, které čtenáři nabízí v podtitulu výzvu: Discover the Czech style of experiential programming (objevte český styl „programování“ zážitku). Singapurská organizace Pivotal Youth v roce 2018 objednala kurz, který nazvala Learning the Czech method - a new method of designing experiential learning (Výuka české metody - nová metoda navrhování zážitkového učení). Potvrzují se tak slova Václava Břicháčka (1992): „Bud’me sví - tím budeme evropští a mnozí se k nám budou chodit učit."

15) V průběhu uplynulých desetiletí vyšla postupně řada knižních titulů věnujících se zkušenostem z oboru výchovy v př́rodě a připravených autory spojenými s lipnickou Prázdninovou školou. Kromě publikace Martin a kol. (2004), která vyšla i v českém překladu (Franc et al., 2007), je to dále také Hanuš a Hanuš (2016) nebo Gintel (2019). Od roku 2004 vychází časopis Gymnasion, „půlročník“ věnovaný zážitkové pedagogice každé z čísel (vycházejí dvě do roka) se věnuje tématu, který se dotýká výchovy, zážitku. Po několika letech (2004-2008), kdy jeho vydavatelem byla Prázdninová škola Lipnice, se této role ujal Nadační fond Gymnasion. 


\section{Dvě poznámky závěrem}

Poslední dvě desetiletí novověku výchovy v př́rodě je tomuto oboru - jak bylo uvedeno výše - také věnována zasloužená pozornost na vysokých školách: nejen jako učebnímu oboru, ale také jako předmětu zkoumání, zpracovávání zkušeností a publikování. Významným příspěvkem je titul Zážitková pedagogika (Jirásek, 2019). Pokud se text tohoto článku věnuje i vývoji pojmů, které jsou s pobytem a výchovou v prŕrodě svázány (od pobytu přes rekreaci k výchově až k pedagogice zážitku), tak je v této souvislosti důležitý i podtitul tohoto záslužného díla: Teorie holistické výchovy (v př́rodě a volném čase). Autor zavádí do českého prostoru dosud nepř́liš používaný pojem holistická (celostní) výchova - najdeme ho ale také již v názvu staršího titulu (Martin et al., 2004). Ivo Jirásek (2019, s. 19) jej vykládá takto: jde o „záměrné ovlivňování prostřednictvím praktického působení na jedince i skupiny s cílem jejich proměny pomocí dramaturgicky navržených a inscenovaných prožitkových situací, zejména $v$ prŕrodě, obvykle s jejich reflektivním převedením ve zkušenost". Zde užitý přívlastek holistická v sobě ukrývá skutečnost, že více než ono „kde“ (v přírodě) a „kdy“ (ve volném čase) je důležitější snažení pedagoga zasáhnout celou osobnost. Pokud nacházíme ve výchově $v$ př́rodě řadu zkušeností a poznatků využitelných v prostoru zážitkové pedagogiky, tak připomeňme další slova autora (2019, s. 19): „zážitková pedagogika = teoretická a vědecká reflexe holistické výchovy“. A tedy, pokud se $\mathrm{v}$ textu tohoto článku hovoří o zážitkové pedagogice, správně by mělo být užito pojmu holistická výchova. Jeho autor dosud ale užívání tohoto pojmu nepřivykl, i když přijal potřebu pojmenovanou Jiráskem (2019, s. 19-20) rozlišit $\mathrm{v}$ tomto oboru teoretickou a praktickou rovinu.

A na úplný závěr: pokud je text zaměřen na výchovu v prrírodě, je dobré připomenout, že autor uvažuje především o jednorázových projektech (akcích, kurzech) délky nejméně jednoho týdne a má na mysli zejména projekty pro dospívající a dospělé. Připomeňme ale, že výchově v přírodě se věnuje řada organizací, sdružení a spolků, zejména pro věk dětský (např. Junák), celoročně. Dlouhodobé pravidelné výchovné působení má svoje specifika, kterým se tento text nevěnuje. Společným jmenovatelem jsou ale právě tyto vícedenní až několikatýdenní projekty, zejména (ale nejenom) letní akce a tábory, které mohou využít - a také velmi často využívají - zkušenosti z projektů jednorázových, jimž se tento text věnuje. 


\section{Literatura}

Alexander, R. (1991). Pohled na Prázdninovou školu ze zahraničí. Instruktorská pošta - interní periodikum Prázdninové školy Lipnice, (1), 1-3.

Bakalár̆, E. (1976). I dospělí si mohou hrát. Pressfoto.

Břicháček, V. (1992). Jabné anebo poslání university. Lipnické metodické listy, (1), 3-4.

Břicháček, V. (1997). Náprava věcí lidských je záležitostí malých skupin. PROPSY: Časopis pro moderní psychologii, 3(4), 1.

Drahanská, P. (2020). Učení prožitkem. Jak postavit vaše rozvojové, výchovné a vzdělávací projekty na prožitku. P. Drahanská.

Fischerová, E. (Ed.). (1957). Pionýrské tábory ROH. Práce.

Franc, D., Martin, A., \& Zounková, D. (2007). Učení zážitkem a hrou: praktická př́ručka instruktora. Computer Press.

Gintel, A. (Ed.). (1980). Prázdniny v pohybu anebo rukovět' pro prázdninové pedagogy. Mladá fronta.

Gintel, A. (Ed.). (2019). Zahrady pozemských radostí. Pohled z dějin výchovy v př́rodě. Gasset.

Halada, V. (2010). Z Lipnice do světa. In A. Gintel (Ed.), Sborník přednášek z konference ke 40. výročí střediska pro výchovu v př́rodě u Lipnice nad Sázavou (s. 40-41). Gasset.

Hanuš, M., \& Hanuš, R. (Eds.). (2016). Instruktorský slabikář: metodická př́ručka pro všechny, kdo organizují kurzy zážitkové pedagogiky. Nadační fond Gymnasion.

Hilská, V. (Ed.). (2013). Zlatý fond her IV. Portál.

Holec, O., Břicháček, V., Hanuš, R., Holcová, M., Holeyšovský, J., Klusáček, M., Lata, J., Paša, L., Smékal, V., Stránský jr, B., \& Svatoš, V. (1994). Instruktorský slabikář. Prázdninová škola Lipnice.

Holec, O. (2007). Příběh Lipnice. Gymnasion, 7(jaro), 105-109.

Hora, P. (1984a). Prázdninová škola '84. Mladý svět.

Hora, P. (1984b). Prázdniny se šlehačkou. Mladá fronta.

Hrkal, J., \& Hanuš, R. (Eds.). (1998). Zlatý fond her II. Portál.

Jirásek, I. (2013). Allan Gintel. Zážitková pedagogika a výchova v př́rodě: cesty vedou dál. Universita Palackého.

Jirásek, I. (2019). Zážitková pedagogika: teorie holistické výchovy (v přírodě a volném čase). Portál.

Koura, P. (2016). Protektorátní školák a jeho volný čas. https://skolakemvprotektoratu.pamatnikterezin.cz/index.php. Památník Terezín.

Kujal, B. (1973). O socialistickou školu budoucnosti. Pedagogika, 22(6), 675-701.

Letní Ústřední tábornická škola Slunečná paseka, 1971. Poslední pokyny. Archiv autora.

Martin, A., Franc, D., \& Zounková, D. (2004). Outdoor and experiental learning: An holistic and creative approach to programme design. Gower Publishing.

Metodické listy (1977). Seminář na pokračování - Opatření k dalšímu rozvoji moderních forem pobytu v př́rodě v SSM. Metodické listy pro tělovýchovně brannou činnost, 1977(3), 18.

Nečasová, D. (2018). Nový socialistický člověk: Československo 1948-1956. Host.

Neuman, J. (2000). Organizace rozvíjející aktivity v př́rodě a jejich výchovné působení. In J. Neuman (Ed.), Turistika a sporty v prrírodě. Přehled základních znalostí a dovedností pro výchovu v př́rodě (s. 186-191). Portál. 
Neuman, J., \& Hanuš, R. (2007). Kristova léta školy prázdninového času. Gymnasion, 7(jaro), $17-55$.

Neuman, J. (2011). Úvodní kapitoly pro teorii a metodiku kurzů výchovy v prrírodě. Občanské sdružení Projekt Odyssea.

Pavelková, M. (2015). Charakteristika rodiny a (pře)výchovy v komunistické perspektivě. Caritas e Veritas, 5(1), 123-134.

Snopek, V. (1969). Tábornická škola. Mladá fronta.

Stránský, B. st. (2010). První byl instruktorský sbor. Sborník přednášek z Konference ke 40. výročí střediska pro výchovu v prŕrodě u Lipnice nad Sázavou. Gasset.

Svatoš, V. (2020). Nejkvalitnější nápady vznikají v brainstormingu fyzicky prrítomných lidí. [Podcast]. https://www.zkusenostniuceni.cz/2020/09/22/

Svojsík, A. B. (1912). Základy junáctví. České lidové knihkupectví a antikvariát Josef Springer.

Šálek, Z. (1983). Vstup do hry. In Z. Šálek (Ed.), Dones oheň a zvítězíš (s. 5-6). Mladá fronta.

Šálek, Z. (1988). Deset sluncí nad Lipnicí. Mladý svět, 30(18).

Štorch, E. (1929, 2018). Dětská farma. http://www.archiv.prirodniskola.cz/knihy-publikace/ detska-farma.html

Třešňák, P. (2020). Proč děti nečtou. Respekt, 2020(45). https://www.respekt.cz/ tydenik/2020/45/proc-deti-nectou?issueId=100482

Vaštová, S. (2019). Štafeta osobností. Gymnasion, 13(2), 99-105.

Zapletal, M. (Ed.). (1990). Zlatý fond her. Mladá fronta.

Zounková, D. (Ed.). (2007). Zlatý fond her III. Portál.

\title{
Autor
}

Ing. Otakar Holec, Šaumannova 2000/18, 61500 Brno, e-mail: ota.holec@gmail.com

\section{Through the history of outdoor education in Czechia to Vacation School Lipnice}

\begin{abstract}
The text deals with the history of outdoor activities in the Czechia especially the moments that fundamentally influenced today's concept of outdoor education (represented mainly by the Prázdninová škola Lipnice - Vacation School Lipnice) and the use of its programs, procedures and methods in holistic education, reflected by experiential pedagogy.
\end{abstract}

Keywords: outdoor education, experiential pedagogy, holistic education, the stay in outdoor, holiday pedagogy, leisure time pedagogy, Prázdninová škola Lipnice, school for outdoor activities, scouting 